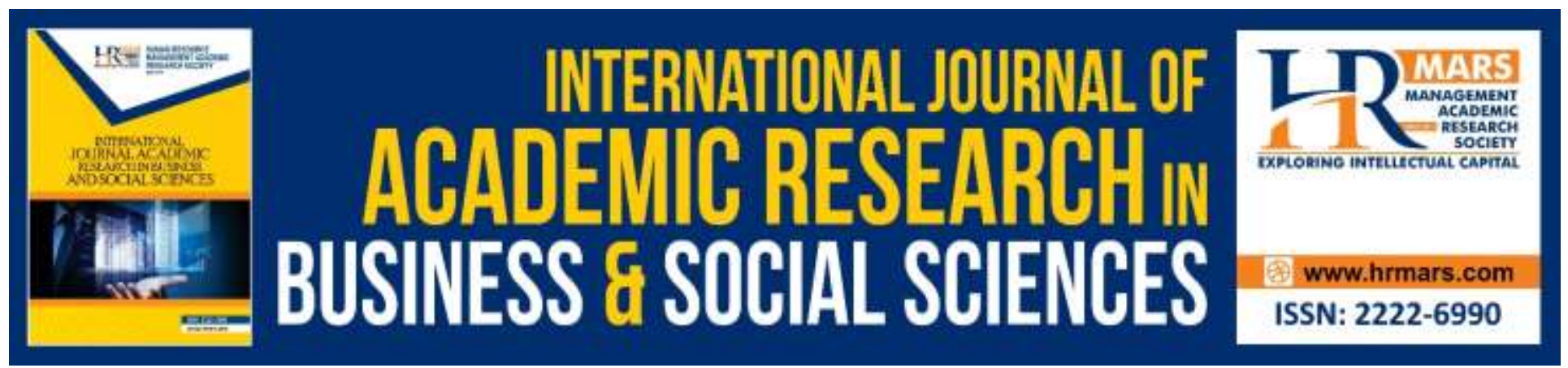

\title{
Trade Liberalization and Labor Demand in Indonesia
}

\section{Rossanto Dwi Handoyo, Fiqy Rabbanisyah, Abdul Rahim Ridzuan, Mohamad Idham Md Razak}

To Link this Article: http://dx.doi.org/10.6007/IJARBSS/v10-i5/7246

DOI:10.6007/IJARBSS/v10-i5/7246

Received: 25 March 2020, Revised: 30 April 2020, Accepted: 09 May 2020

Published Online: 30 May 2020

In-Text Citation: (Handoyo et al., 2020)

To Cite this Article: Handoyo, R. D., Rabbanisyah, F., Ridzuan, A. R., \& Razak, M. I. M. (2020). Trade Liberalization and Labor Demand in Indonesia. International Journal of Academic Research in Business and Social Sciences, 10(5), 753-761.

\section{Copyright: (C) 2020 The Author(s)}

Published by Human Resource Management Academic Research Society (www.hrmars.com)

This article is published under the Creative Commons Attribution (CC BY 4.0) license. Anyone may reproduce, distribute, translate and create derivative works of this article (for both commercial and non-commercial purposes), subject to full attribution to the original publication and authors. The full terms of this license may be seen

at: $\underline{\text { http://creativecommons.org/licences/by/4.0/legalcode }}$

Vol. 10, No. 5, 2020, Pg. 753 - 761

http://hrmars.com/index.php/pages/detail/IJARBSS

JOURNAL HOMEPAGE

Full Terms \& Conditions of access and use can be found at http://hrmars.com/index.php/pages/detail/publication-ethics 


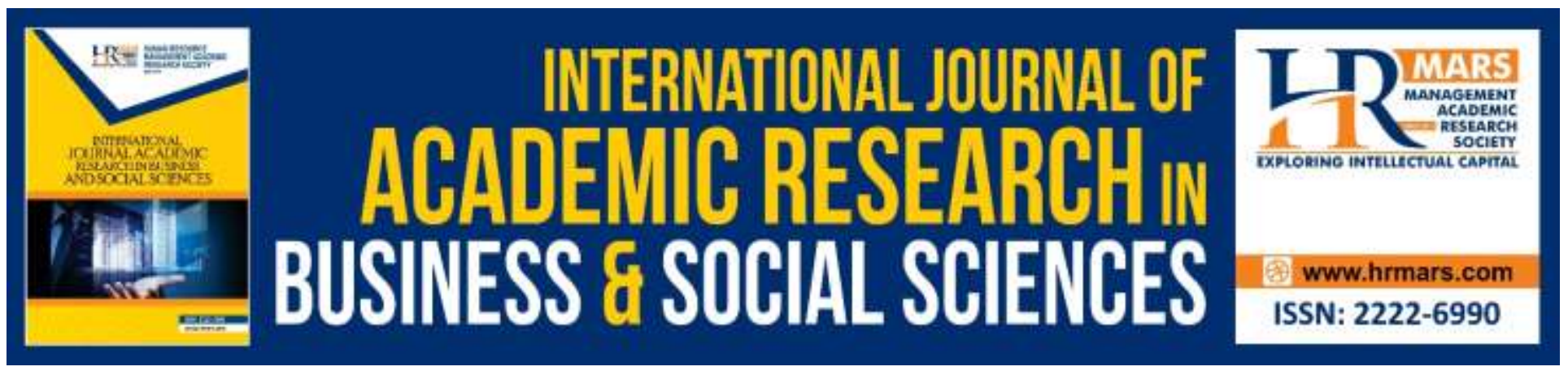

\title{
Trade Liberalization and Labor Demand in Indonesia
}

\author{
Rossanto Dwi Handoyo, Fiqy Rabbanisyah \\ Faculty of Economics and Business, Universitas Airlangga, Indonesia \\ Email: Rossanto_dh@feb.unair. ac.id, fadhlillah29@gmail.com
}

\begin{abstract}
Abdul Rahim Ridzuan, Mohamad Idham Md Razak
Faculty of Business and Management, Universiti Teknologi MARA, Melaka Campus, Malaysia Email: Rahim670@staf.uitm.edu.my, iedham@warga.uitm.edu.my
\end{abstract}

\begin{abstract}
Trade liberalization agreement creates great opportunities to enhance economic among participating countries. Trade liberalization would inevitably affect the factors of production within countries. The aim of the study is to analyze the impact of trade liberalization on labor demand in manufacturing industries in Indonesia. This study employs industrial manufacturing firm-level data over the period 2008-2013 and was estimated using panel data regression analysis, the Fixed Effect Method. The results indicate that tariff rates, value-added, imports of raw materials, and export significantly affect the labor demand. Furthermore, labor wages have negatively affected the labor demand of Indonesian manufacturing industry.
\end{abstract}

Keywords: Trade Liberalization, Labor Demand.

\section{Introduction}

Trade liberalization has become a worldwide blueprint among countries to establish an open market with significantly few barriers to trade. It aims to stop or reduce state intervention in the form of entry barriers (tariffs and quotas) on trade and the international economy (Mayana, 2004). Theories regarding trade liberalization were first put forward by the classical economists Adam Smith (1776), which emphasized that international trade occurs when there is an absolute advantage in a country. Ricardo (1817) stated that international trade is based on the comparative advantage of each country.

Currently, trade liberalization has spread to the whole world, including the collective countries of Southeast Asia, ASEAN (Association of Southeast Asian Nations). On January $28^{\text {th }}, 1992$, in Singapore, several countries joined ASEAN, namely Indonesia, Singapore, Brunei Darussalam, Malaysia, the Philippines and Thailand as they signed a trade liberalization agreement called AFTA (ASEAN Free Trade Area). The goal is to make ASEAN region as a competitive production base to attract more foreign direct investment in ASEAN, as well as increasing trade among members of ASEAN (Regional and Bilateral Policy Center, 2012). 
In Indonesia, years after the signing of the AFTA trade liberalization agreements, there were declines in the value of the average tariff on all trade products from $12.51 \%$ in 1993 to be $4.66 \%$ in 2013 (See Figure 1). In the same period, there was also an increase in the total workforce in Indonesia. Since 1993, the number of workers in Indonesia amounted to 76.72 million and continued to rise, as seen in the year 2013, with 110.8 million workers. However, it was unclear whether the effect of the increase in variable labor was associated with trade liberalization.

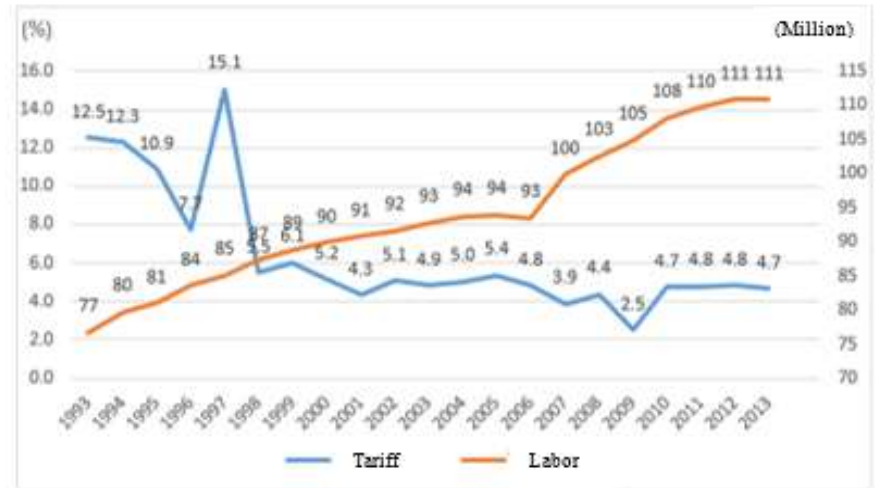

*Source: World Integrated Trade Solutions (WITS) and the Central Bureau of Statistics, processed Figure 1. Movement Rates (in percent) and labor (in millions) in Indonesia in 1993-2013

Based on previous research by Mitra and Shin (2012), Mouelhi and Ghazali (2013) and Njikam (2016), the survey of the manufacturing industry was used to see the impact of trade liberalization on labor demand. In line with these studies, this research uses industry-level data. Generally, during the liberalization of trade, the level of the tariff for the manufacturing sector was the highest compared to other sectors (Mouelhi and Ghazali, 2013). This situation indicates that the manufacturing sector is the sector within the category of "government-controlled" (Njikam, 2016). The Ministry of Industry (2016) stated that the manufacturing industry in Indonesia is accounted for $65 \%$ of employment. This situation shows that there is a strategic role of manufacturing industry on generating employment in Indonesia. Therefore, the data of the manufacturing industry can show the contribution of this industry on employment in Indonesia during the liberation trade period.

Based on the discussion above, this study uses the variables used in the previous studies. This study sought to examine the impact of trade liberalization through the variables of tariff rate on imported raw materials, value-added, imports of raw materials, labor costs and the value of exports to the labor demand using firm-level data in the Indonesian manufacturing industry. Besides supporting the literature, this study serves as a reference and benchmark to identify which of these policies have affected the level of market openness in Indonesia and its relation to labor demand.

\section{Liberalization of the Labor Demand}

Trade liberalization, according to Rodrik (1997), is a condition in which trade was at a more open market condition (international trade) through the reduction of related barriers that exist in the market.

Rodrik (1997) mentions two paths that show the effect of trade liberalization that led to the demand for labor. The first path, trade liberalization allows the import of raw materials, inputs of capital and work-in-process goods for processing in the importing country. The second path is 
associated with the Marshallian demand. Through trade liberalization, the company will increase output efficiently by reducing the amount of labor. The linkage between trade liberalization and labor demand expressed by Rodrik (1997) is closely associated with international trade theory propounded by Hechscher-Ohlin (1933), in which international trade will be carried out by both labor-intensive industry and capital intensive industry (capital intensive). Trade liberalization will be a positive influence in adding labor for the labor-intensive industries. However, trade liberalization also negatively affects the demand for labor, because there will be a process of substitution between the almost-finished raw material and the use of domestic labor.

\section{Analysis Model}

Panel data regression model was used to examine the relationship of trade liberalization variable with labor demand. The Econometric equations in this study were formulated as follows:

$$
\log T K_{i t}=\beta_{1}+\beta_{2} \log V A_{i t}+\beta_{3} \log I M_{i t}+\beta_{4} \text { persentarif }_{i t}+\beta_{5} \log w_{i t}+\beta_{6} \log E X_{i t}+\varepsilon_{i t}
$$

Information:

$\begin{array}{ll}T K_{i t} & : \text { Total employment in the industry } i \text { The period (years) } \mathrm{t} \\ V A_{i t} & : \text { The value-added of industry } \mathrm{i} \text { in period (years) } \mathrm{t} \\ I M_{i t} & : \text { Imported raw material in the industry } \mathrm{i} \text { in period (years) } \mathrm{t} \\ \text { persentarif }_{i t}: \text { The tariff rate of imported raw material in the industry in period (years) } \mathrm{t} \\ w_{i t} & : \text { Labor Wages in industry } i \text { The period (years) } \mathrm{t} \\ E X_{i t} & : \text { The export value of the industry } i \text { The period (years) } \mathrm{t} \\ \varepsilon_{i t} & : \text { Error Term }\end{array}$

\section{Research Methods}

The dependent variable in this study is the total labor force manufacturing industry that illustrates the demand for labor. The indicators of total employment were observed from the number of workers in each classification of the manufacturing industry in Indonesia. The independent variables in this study are the sum of value-added, the tariff rate on imported raw materials, imported raw materials, labor wages, and the value of exports. This study used panel data regression, with cross-section data includes 17677 Indonesian companies in the manufacturing industry. The data were then classified into nine industry classifications, namely food, beverages, and tobacco; textiles and textile processed products; furniture and processed forest products; footwear and leather products; industrial metals and metal products; paper and paper products; chemical and pharmaceutical industries; rubber and plastics industry; and other industries. The study used timeseries data from the period 2008-2013. The data was sourced from the Company Annual Survey of Big and Medium Manufacturing Industry, BPS and WITS in the World Bank.

The variable for labor demand or total labor was derived from the number of production workers and other workers working in every manufacturing company that has been divided into each classification each year. The variable of Tariffs on imported raw materials in this study is Tariffs MostFavored Nation (MFN) dutiable imports for each sector of the manufacturing industry. The variable of value-added production was measured by dividing the value of output per manufacturing company in a different class to the Consumer Price Index (CPI). The variable of imported raw materials was obtained from dividing the total of imported raw materials with the CPI. The variable of wage is the average wage of workers, as obtained from the result of total labor costs divided by the total 
INTERNATIONAL JOURNAL OF ACADEMIC RESEARCH IN BUSINESS AND SOCIAL SCIENCES

Vol. 10, No. 5, May, 2020, E-ISSN: 2222-6990 ㄷ 2020 HRMARS

workforce in any manufacturing industries company divided by CPI. The variable of export value was derived from multiplying the percentage of exports in the manufacturing sector in a different year with a total output of companies in each sector, which then was divided by CPI.

\section{Results}

This research used panel data, and regression was computed by using Pooled Least Square, Random Effect Model and Fixed Effect Model. According to Hausman, the best model is the Fixed Effect Model. Therefore, the model was estimated using the Fixed Effect Model as shown in Table 1.

Table 1. Effect of Variable in Trade Liberalization on Labor Demand in Indonesian Manufacturing Industry 2008-2013

\begin{tabular}{ll}
\hline Variable & Coefficient \\
\hline $\begin{array}{l}\text { Dependent variable : } \log T K \\
\text { (Labor Demand) }\end{array}$ & \\
Constants & 2.339 \\
& {$[0.000]$} \\
Value Added (logVA) & 0.218 \\
& {$[0.000]$} \\
Imported Raw Material (logIM) & 0.007 \\
& {$[0.000]$} \\
Tariff of Imported Raw & -0.039 \\
Material (persentatif) & {$[0.000]$} \\
Labor Wages (logw) & -0.028 \\
& {$[0.000]$} \\
Exported Values (logEX) & 0.003 \\
& {$[0.000]$} \\
\hline Obeservation & 106.062 \\
\hline R-squared & 0.6378 \\
\hline F-statistic & 3547.66 \\
\hline Prob > F & 0.0000 \\
\hline *Source: Data processed & \\
$*$ Description: Figures in brackets [ ] stated p-value
\end{tabular}

Table 1 shows Prob> F was valued at number 0.0000 , less than the level of significance $\alpha$ by 1 percent, and the $p$-value for each variable would state that either simultaneously or partially, the independent variable in our model is significantly affected the dependent variable.

The coefficient in Table 1 shows the different number and notations on each variable. Variable of value-added $(\log V A)$, raw material imports ( $\log I M)$, and exports (logEX) have significant positive effect on labor demand variables (logTK), with the coefficient values of $0.218,0.007$ and 0.003 , respectively. Furthermore, the variable of tariffs on imported raw materials (persentarif) and labor wages (logw) have a significant negative effect on the labor demand (logTK), with the coefficient values of 0.039 and 0.028 , respectively.

These findings indicate that an increase of one percent in each of the added value, raw material import and export value, it will significantly increase the demand for labor in the 
manufacturing industry to 0.218 percent, 0.007 percent and 0.003 percent. Conversely, a negative relationship was seen in the variable of tariffs on imported raw materials, and labor wages to labor demand. The results indicate that an increase of one percent on imported raw materials, tariffs, and labor wage, it would significantly reduce the demand for labor, at 0.039 and 0.028 percent, respectively.

Table 2 shows the results of the estimation of each variable that describe the sectoral trade liberalization on the manufacturing industry in Indonesia during the period 2008-2013 using Fixed Effect Method. Table 2 shows the significance of all variables. Food, beverages and tobacco sectors significantly affect the demand for labor in the industry. The influence shown in the sector of food, beverages, and tobacco industry has a similar effect with the variables of trade liberalization on labor demand in the Indonesian manufacturing industry.

Table 2. Variables Influence on Trade Liberalization on Labor Demand Manufacturing Industry Sectoral Indonesia in 2008-2013

\begin{tabular}{|c|c|c|c|c|c|c|c|c|c|}
\hline & $\begin{array}{c}\text { Food, Beverage, } \\
\text { and Tobaco }\end{array}$ & $\begin{array}{c}\text { Textile and } \\
\text { apparel }\end{array}$ & $\begin{array}{c}\text { Furniture } \\
\text { and Fo rest } \\
\text { Product }\end{array}$ & $\begin{array}{c}\text { Footwe ar and } \\
\text { Leather } \\
\text { Product }\end{array}$ & $\begin{array}{c}\text { Metal and } \\
\text { Metal Porduct }\end{array}$ & $\begin{array}{l}\text { Paper and } \\
\text { Paper } \\
\text { Product }\end{array}$ & $\begin{array}{l}\text { Chemistry and } \\
\text { Pharmacy }\end{array}$ & $\begin{array}{c}\text { Rubber and } \\
\text { Plastic }\end{array}$ & $\begin{array}{c}\text { Other } \\
\text { Ind ustry }\end{array}$ \\
\hline Constanta & 2.559 & 9.733 & 1.025 & 0.058 & 2.621 & 3.432 & 2.651 & 2.892 & 1.824 \\
\hline $\begin{array}{l}\text { Value Added (log } \\
\text { VA) }\end{array}$ & 0.182 & 0.268 & 0.317 & 0.354 & 0.19 & 0.162 & 0.179 & 0.172 & 0.195 \\
\hline $\begin{array}{l}\text { Imported Raw } \\
\text { Materials (log IM) }\end{array}$ & 0.014 & 0.003 & 0.005 & 0.004 & 0.002 & 0.003 & 0.003 & 0.006 & 0.007 \\
\hline $\begin{array}{c}\text { Imported Raw } \\
\text { Materials Tariff } \\
\text { (Persen Tariff) }\end{array}$ & -0.425 & 97.866 & 3.485 & 9.691 & -1.79 & -10.087 & -0.411 & -0.26 & 10.085 \\
\hline Wages (log W) & -0.022 & -0.021 & -0.031 & -0.036 & -0.043 & -0.051 & -0.042 & -0.027 & -0.27 \\
\hline $\begin{array}{l}\text { Export Value (log } \\
\text { EX) }\end{array}$ & -0.005 & 0.007 & 0.002 & 0.003 & 0.014 & 0.004 & 0.006 & 0.005 & 0.003 \\
\hline Observation & 4755 & 3365 & 1791 & 524 & 731 & 410 & 933 & 1327 & 3841 \\
\hline R-squared & 0.624 & 0.755 & 0.724 & 0.805 & 0.622 & 0.719 & 0.468 & 0.567 & 0.652 \\
\hline
\end{tabular}

*Source: Data processed

*Description: The yellow color indicates significant figures

All variables showed that trade liberalization had affected significantly the demand for labor in the manufacturing of textile and apparel, furniture and processed forest products, as well as the chemical and pharmaceutical industry. However, several variables showed different results in the analysis of the manufacturing industry as a whole. Additionally, the variables of imported raw material and export value in the industrial sector of footwear and leather products, metal and metal products, variable of import raw materials, tariffs of imported raw material and exports value for the paper and paper products industry and the variable of tariffs on imported raw materials did not significantly affect the demand for labor in the manufacturing sector of rubber and plastic in Indonesia.

\section{Discussion And Conclusion}

This study aims to analyze the impacts of trade liberalization on labor demand in Indonesia. The value-added has a positive and significant impact on the demand for labor. This study is consistent with the theory expressed by Cobb-Douglas, where demand for labor will arise because of the demand for the output. From these results, it can be said that the existence of trade liberalization 
agreements in Indonesia has positively managed to trigger value-added manufacturing, and it is accompanied by an increase in the demand for labor.

Imported material raw has a positive and significant impact on the demand for labor in the manufacturing industry in Indonesia. The existence of trade liberalization agreements in Indonesia has lowered the barriers for both tariff and non-tariff for goods imported to the country.

The existence of trade liberalization agreements in Indonesia has positively triggered some increases in imported raw materials, which further led to an increase in the demand for labor to process the raw materials.

Tariff of imported raw material has a significant negative effect on the demand for labor in the manufacturing industry in Indonesia. This research obtained the results that the decrease in tariff rates has managed to increase the demand for labor, and the results align with previous research.

The findings of this study stated that trade liberalization agreements have an impact on the increase in the demand for imported raw materials in the manufacturing industry in Indonesia. During the period of implementation of the agreement, the agreement encourages the increase in demand for labor. This positive relationship between trade liberalization with labor demand is evident in this study.

The findings of this study stated that when trade liberalization agreements were applied in Indonesia, it impacted wage increases and decreased the demand for labor. Despite the increase in wages caused by trade liberalization has a negative effect on the demand for labor, the level of competition in the labor market is increasing. Potential workers will increase their competence in their by increasing their productivity. This situation was evidenced in the higher value-added in companies. Therefore, trade liberalization agreements did cause a decrease in wages; it still maintained a positive impact on labor productivity.

The value of exports has a positive and significant impact on the demand for labor in the manufacturing industry in Indonesia. The liberalization of trade would push an increase to greater output. Companies that produce labor-intensive goods will tend to increase their workforce, and it has a positive impact on the demand for labor in the manufacturing industry in Indonesia. The condition of export value in Indonesian manufacturing industry showed an upward trend during the period of implementation of trade liberalization.

In the sector of food beverages and tobacco industry, it shows that the demand for labor in the food and beverage industry and tobacco was strongly influenced by the increase in value-added, where the food beverage and tobacco industries have considerable opportunities to enhance their role in the condition of market openness as one of the sectors that absorbs labor.

The use of imported raw materials has significantly affected the demand for labor in the food, beverages and tobacco industry, textile and apparel industry, the furniture and forest product industry, chemical and pharmaceutical industry, rubber and plastics industry, and other industries. This situation shows that the implementation of trade liberalization will increase the intensity of the use of imported raw materials, which in turn, increase the demand for labor in the production process, as the raw materials will increase the demand for labor to produce these materials. The different conditions indicated by the processing industries of footwear and leather products, industrial metals and metal products, as well as paper and paper products industry, in which the value of imports of raw materials for a third of the industrial sector, and it did not significantly affect the demand for labor. This study shows that the trend of using imported raw materials do not affect employment because the use of imported raw materials is relatively small in these industries. 
Alternatively, there is a probability that these three industries are capital-intensive industries (capital intensive).

Tariffs on imported raw materials have a significant effect on the demand for labor in the manufacturing industries of food, beverages and tobacco, textile and apparel industry, the furniture and the forest products industry, footwear and leather products, chemicals and pharmaceuticals, and other industrial sectors. On the other hand, tariffs on imported raw materials have no significant effect on the metal processing and metal products industry, paper and paper products industry, and rubber and plastics industry. This study shows that the food industry beverages and tobacco, and other industrial sectors that have significant influence over the variable rates of imported raw materials caused by the decrease in the tariff of imported raw materials. Subsequently, it will decrease the companies' expense to pay for the imported raw material cost, which results in fund allocation to improve production through an increase in demand for labor.

Overall, the study found that during the implementation of the trade liberalization agreement in Indonesia, it managed to increase the demand for labor through the reduction of tariff rates, increasing the value-added, increasing raw material imports, and increasing the value of exports in the aggregate of the manufacturing industry in Indonesia. On the other hand, trade liberalization agreements also have a negative impact on the demand for labor through an increase in labor costs has impacted the decrease of the overall demand for labor in the manufacturing industry in Indonesia.

In conclusion, trade liberalization has significantly affected the demand for labor in the manufacturing industry in Indonesia. During the period of implementation of trade liberalization agreements, it managed to increase the demand for labor through the variables of reduction of tariffs on imported raw materials, an increase in value-added, an increase in imports of raw materials and an increase in the value of overall exports in the manufacturing industry in Indonesia. On the other hand, trade liberalization agreements also have a negative impact on labor demand through the increased labor wages, which then caused the decrease of the overall demand for labor in the manufacturing industry in Indonesia.

\section{References}

Arifin, S. (2007). Int' I Cooperation Trade: Opportunity and Barrier for Indonesia. Jakarta: Gramedia. Badan Pusat Statistik (BPS). (2012). Labor Concept. Jakarta: BPS.

Badan Pusat Statistik (BPS). (2012) Industry Manufacture. Jakarta: BPS.

Badan Pusat Statistik (BPS). (2013) CPI and Indonesia's Monthly Inflation. Jakarta: BPS. Borjas, G. J. (2016). Labor Economics $7^{\text {th }}$ Edition. New York: McGraw-Hill Education.

Bourguignon, F., \& Goh, Chor-ching. (2016). Trade and Labor Market Vulnerability in Indonesia, Korea, and Thailand. Jakarta: World Bank.

Carbaugh, R. J. (2008). International Economics $11^{\text {th }}$ Edition. USA: Thomson Higher Education.

Chand, S. (1999). Trade liberalization and productivity growth: Time-series evidence from Australian manufacturing. Journal of Economic Literature, 75, 28-36.

Gaddis, I., \& Pieters. J. (2014). The gendered labor market impacts of trade liberalization: Evidence from Brazil. World Bank Policy Research Working Paper. No. 7095. Washington D.C.: World Bank.

Gujarati, D. N. (2004). Basic Econometrics $4^{\text {th }}$ Edition. New York: McGraw-Hill. 
Hasan, R., Mehta, D., Ranjan, P., \& Ahsan, R. N. (2012). Trade liberalization and unemployment: Theory and evidence from India. Journal of Development Economics, 97(2), 269-280.

lyer, K. G., Rambaldi, A. N., \& Tang, K. K. (2009). How trade and foreign investment affect the growth of a small but not so open economy: Australia? Applied Economics. 41, 1525-1532.

Krugman, P. R., Obstfeld, M., \& Marc, J. M. (2012). International Economics Theory and Policy $9^{\text {th }}$ Edition. England: Pearson Education Limited.

Kyophilavong, P. (2013). The effects of AFTA on macroeconomic variables and poverty: Evidence of Laos. JEL Classification. Laos: Faculty of Economics and Business Management, National University of Laos.

Liyanaarachchi, T. S., Naranpanawa, A., \& Bandara, J. S. (2016). Impact of trade liberalization on labour market and poverty in Sri Lanka: An integrated macro-micro modelling approach. Economic Modelling. 59, 102-115.

Mayana, R. F. (2004). Protection of Industrial Design in Indonesia. Jakarta: Grasindo.

McCaig, B. (2011). Exporting out of poverty: Provincial poverty in Vietnam and U.S. market access. Journal of International Economics. 85(1), 102-113.

Njikam, O. (2016). Trade liberalization, labor market regulations and labor demand in Cameroon. International Review of Economics and Finance, 1-17.

Nocke, V., \& Yeaple, S. (2008). An Assignment Theory of Foreign Direct Investment. Review of Economic Studies. 75(2), 529-557.

Organization for Economic Co-operation and Development (OECD). (2005). National Accounts of OECD Countries. Paris: OECD.

Pugel, T. A. (2012). International Economics 15 th Edition. New York: The McGraw-Hill Companies, Inc.

Rodrik, D. (1997). Has Globalization Gone Too Far?. Washington D.C.: Institute of International Economics.

Salvatore, D. (2007). International Economics $9^{\text {th }}$ Edition. USA: John Wiley \& Sons, Inc.

Samuelson, P. A., \& Nordhaus, W. D. (2009). Economics. New York: The McGraw-Hill Companies, Inc.

Todaro, M. P., \& Smith, S. C. (2003). Development Economics in The Third World $8^{\text {th }}$ Edition. Jakarta: Erlangga.

Topalova, P. (2010). Factor immobility and regional impacts of trade liberalization: Evidence on Poverty from India. American Economic Journal: Applied Economics. 2(4), 1-41.

World Bank. (2016). World Development Indicators. Washington D.C.: World Bank.

World Integrated Trade Solutions (WITS). (2010). Types of Tariffs. Washington D.C.: World Bank. 